University of Nebraska - Lincoln

DigitalCommons@University of Nebraska - Lincoln

2001

\title{
Area Requirements of Grassland Birds: A Regional Perspective
}

Douglas Johnson

USGS Northern Prairie Wildlife Research Center, Douglas_H_Johnson@usgs.gov

Lawrence Igl

USGS Northern Prairie Wildlife Research Center, ligl@usgs.gov

Follow this and additional works at: https://digitalcommons.unl.edu/usgsnpwrc

Part of the Other International and Area Studies Commons

Johnson, Douglas and Igl, Lawrence, "Area Requirements of Grassland Birds: A Regional Perspective" (2001). USGS Northern Prairie Wildlife Research Center. 30.

https://digitalcommons.unl.edu/usgsnpwrc/30

This Article is brought to you for free and open access by the US Geological Survey at DigitalCommons@University of Nebraska - Lincoln. It has been accepted for inclusion in USGS Northern Prairie Wildlife Research Center by an authorized administrator of DigitalCommons@University of Nebraska - Lincoln. 


\title{
AREA REQUIREMENTS OF GRASSLAND BIRDS: A REGIONAL PERSPECTIVE
}

\author{
DOUglas H. JOHNSON ${ }^{1}$ AND LAWRENCE D. IGL \\ Northern Prairie Wildlife Research Center, U.S. Geological Survey, 8711 37th Street Southeast, \\ Jamestown, North Dakota 58401, USA
}

\begin{abstract}
Area requirements of grassland birds have not been studied except in tallgrass prairie. We studied the relation between both species-occurrence and density and patch size by conducting 699 fixed-radius point counts of 15 bird species on 303 restored grassland areas in nine counties in four northern Great Plains states. Northern Harrier (Circus cyaneus), Sedge Wren (Cistothorus platensis), Clay-colored Sparrow (Spizella pallida), Grasshopper Sparrow (Ammodramus savannarum), Baird's Sparrow (Ammodramus bairdii), Le Conte's Sparrow (Ammodramus leconteii), and Bobolink (Dolichonyx oryzivorus) were shown to favor larger grassland patches in one or more counties. Evidence of area sensitivity was weak or ambivalent for Eastern Kingbird (Tyrannus tyrannus), Common Yellowthroat (Geothlypis trichas), Savannah Sparrow (Passerculus sandwichensis), and Western Meadowlark (Sturnella neglecta). Red-winged Blackbirds (Agelaius phoeniceus) preferred larger patches in some counties, and smaller patches in others. Mourning Doves (Zenaida macroura) and Brown- headed Cowbirds (Molothrus ater) tended to favor smaller grassland patches. Three species showed greater area sensitivity in counties where each species was more common. Five species demonstrated some spatial pattern of area sensitivity, either north to south or east to west. This study demonstrates the importance of replication in space; results from one area may not apply to others because of differences in study design, analytical methods, location relative to range of the species, and surrounding landscapes. Received October 13, 1999, accepted August 8, 2000.
\end{abstract}

THE Central GRASSLANDS were once North America's most extensive ecosystem, although they have now been brought under submission by settlement. The eastern tallgrass prairie has been nearly completely replaced by intensive agriculture; less than $1 \%$ of the original tallgrass prairie remains in most states and provinces (Samson and Knopf 1994). Although the western shortgrass prairie has experienced fewer losses, native grazers such as bison (Bison bison) and prairie dogs (Cynomys spp.) have been largely replaced by domestic cattle, which exhibit very different grazing behaviors and have different effects on vegetation (Peden et al. 1974, Schwartz and Ellis 1981). The mixedgrass prairie, lying between the tallgrass and the shortgrass prairies, has suffered from similar influences.

Associated with that massive scale conversion of prairie has been a concomitant change in communities of birds and other animals that rely on grassland habitats. Historical accounts tell of rich abundances of prairie wildlife that now can be only imagined (e.g. Dinsmore 1994). Widespread and systematic surveys of

\footnotetext{
${ }^{1}$ E-mail: douglas_h_johnson@usgs.gov
}

most bird species did not begin until the mid 1960s, with the advent of the North American Breeding Bird Survey (BBS; Robbins et al. 1986). Thus, quantitative evidence of changes in grassland bird populations exists for only the past 30 years or so, well after most grassland losses occurred. Nonetheless, the BBS indicates that many grassland birds have fared poorly, even during that period. BBS results indicate that, during 1966-1996, grassland-nesting birds had the lowest proportion of species with increasing population trends than of all avian guilds in North America (Peterjohn and Sauer 1999). In North Dakota between 1967 and 1992-1993, numbers of Baird's Sparrows (Ammodramus bairdii), Savannah Sparrows (Passerculus sandwichensis), Chestnut-collared Longspurs (Calcarius ornatus), and Western Meadowlarks (Sturnella neglecta) declined by $39 \%$ or more; Clay-colored Sparrows (Spizella pallida) and Bobolinks (Dolichonyx oryzivorus) declined at lesser rates (Igl and Johnson 1997).

Although it is convenient to attribute declines of grassland bird populations to losses of native grassland, habitat loss is but the first of three main concerns involving the breeding grounds. A second issue is degradation of re- 
maining tracts of grassland because of improper or inadequate management, disruption of natural disturbance regimes, encroachment of woody and exotic vegetation, and other factors.

In addition to the loss of grassland and the inadequate management applied to extant grassland, a third issue is fragmentation. Habitat fragmentation involves separation of large, contiguous areas of habitat into smaller patches that are isolated from one another. Three types of fragmentation effects can be distinguished: patch-size, edge, and isolation (e.g. Wiens 1995, Johnson and Winter 1999). Patch-size effects are those that cause use or reproductive success to differ among habitat patches of different sizes. Some patch-size effects may be induced by edge effects-phenomena such as avoidance, predation, competition, or brood parasitismthat operate at different levels near a habitat edge than in the interior of a habitat patch. In addition, isolation from similar habitat can affect use of a particular patch by influencing dispersal or habitat use. Here we deal only with effects of fragmentation on occurrence or density of birds using a habitat patch; see Johnson and Winter (1999) for a more general review.

Concerns about habitat fragmentation first arose with respect to temperate forest patches in agricultural landscapes (e.g. Bond 1957, Gates and Gysel 1978, Robbins et al. 1989). Samson (1980) was the first to examine fragmentation effects in grassland birds, at a time when the problems owing to passive sampling were not widely recognized (Connor and McCoy 1979). He sampled greater areas of the larger grassland sites. Thus, one would expect him to find more birds of more species, especially uncommon species, in larger grasslands. The likelihood of finding a species is greater not necessarily because that species requires large patches, but simply because that species is uncommon and less likely to be found in any small area searched, regardless of the size of the patch that is searched (Connor and McCoy 1979, Haila and Järvinen 1981, Johnson unpubl. data). That unequal sampling effort left his conclusions unsupported. Similarly, certain results of Johnson and Temple (1986), another early study, also are suspect owing to the potential influence of passive sampling, as well as other concerns (Johnson unpubl. data).

Some recent studies of fragmentation and grassland birds (e.g. Herkert 1994, Vickery et al.
1994, McMaster and Davis 1998, Winter 1998) overcame the passive-sampling problem by surveying equal-sized areas in all patches. Bollinger (1995) avoided the passive-sampling problem by relating densities of birds, rather than frequency of occurrence, to field size and other explanatory variables.

Some investigators (Wiens 1969, Delisle and Savidge 1996, Helzer 1996) have detected an avoidance of edge by grassland birds, which can induce patch-size effects. Most studies took place within a relatively small area, such as part of a state, but it is important to examine larger areas, to see how consistent any phenomena are (Tewksbury et al. 1998). It is also critical to consider the landscape in which the studies were conducted. Patch-size effects may be manifested differently in highly fragmented and less fragmented landscapes (Donovan et al. 1997).

In this paper, we examine the influence of fragmentation and isolation of Conservation Reserve Program (CRP) grassland fields on grassland breeding bird populations in the northern Great Plains. The CRP has had enormous influence on the landscape of the Great Plains, where millions of hectares of cropland have been replanted with perennial grassland vegetation (Johnson et al. 1994). Those changes have markedly influenced the bird communities associated with those lands (Johnson and Igl 1995).

Our study differs from most others with regard to the area requirements of grassland birds in three fundamental respects. First, most other studies (except McMaster and Davis 1998) were conducted in tallgrass prairies and eastern grasslands, often well outside the Great Plains. Our study took place in the heart of North America's prairie region, in the northern Great Plains. Second, whereas other studies mostly involved native prairies, our fields were retired cropland planted with perennial grasses and legumes, usually non-native species, such as wheatgrasses (Agropyron spp.), brome grasses (Bromus inermis, B. japonicus), and alfalfa (Medicago sativa) (Johnson and Schwartz 1993b). Nonetheless, breeding bird assemblages associated with our fields were very similar to those in idle native grasslands in the same region (cf. Johnson and Schwartz 1993a, Johnson 1996, Winter et al. 1999). 


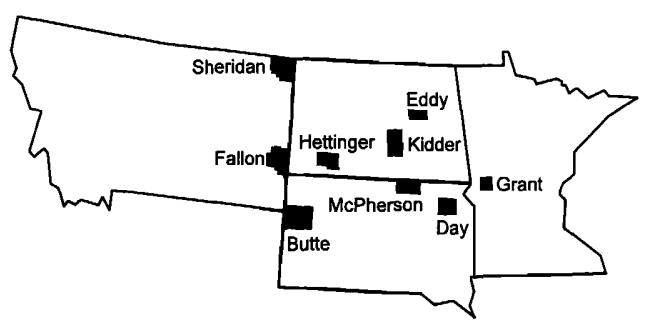

FIG. 1. Counties in the northern Great Plains in which Conservation Reserve Program fields were surveyed for breeding birds.

Third, and most important, our study sites had a greater spatial dispersion. Most other grassland studies of patch size involved a single sample of sites in fairly close proximity, usually within one state. We were able to study groups of sites (an average of 34) within each of nine counties in four states; sites varied up to $450 \mathrm{~km}$ east to west and $225 \mathrm{~km}$ north to south (Fig. 1). The combination of intensive sampling repeated over an extensive area enabled us to conduct a separate analysis for each county. Using those results, we could essentially perform a meta-analysis (e.g. Hedges and Olkin 1985), look for geographical patterns in area-sensitivity, and relate area-sensitivity to density of a species in an area.

\section{STUdy AREAS AND METHODS}

Study areas. - Study areas were CRP fields in eastern Montana, North Dakota, South Dakota, and western Minnesota (Table 1, Fig. 1). We selected nine counties for sampling to include one county that would represent each major physiographic region (Great Plains Roughlands, Missouri Coteau, Drift Prairie, and Black Prairie) within the grassland areas of each state (Johnson and Schwartz 1993b: Fig. 1). In each county, we selected fields with a broad range of sizes (Table 1). All were dominated by grassy or other herbaceous vegetation; most $(70 \%)$ had been planted with introduced grasses and legumes (Johnson and Schwartz 1993b).

Field methods.-In each CRP field, we surveyed breeding birds by conducting point counts on randomly selected circular plots. Number of circular plots in a CRP field was approximately proportional to size of the field, and ranged from one to eight. (We circumvented potential problems associated with passive sampling by the use of our analytic methods, which are described below.) Plots were located roughly uniformly throughout the field, avoiding edges when possible. Field personnel were trained for making distance estimates and bird identification
TABLE 1. Number of Conservation Reserve Program fields in the northern Great Plains in which point counts were conducted; number of point counts; and minimum, median, and maximum size of grassland patch containing fields.

\begin{tabular}{|c|c|c|c|c|c|}
\hline \multirow[b]{2}{*}{ County } & \multirow{2}{*}{\multicolumn{2}{|c|}{$\begin{array}{l}\text { Num- } \\
\text { Num- ber of } \\
\text { ber of point } \\
\text { fields counts }\end{array}$}} & \multicolumn{3}{|c|}{$\begin{array}{l}\text { Size of grassland } \\
\text { patch (ha) }\end{array}$} \\
\hline & & & $\begin{array}{l}\text { Mini- } \\
\text { mum }\end{array}$ & $\begin{array}{l}\text { Medi- } \\
\text { an }\end{array}$ & $\begin{array}{l}\text { Maxi- } \\
\text { mum }\end{array}$ \\
\hline \multicolumn{6}{|c|}{ Great Plains Roughlands } \\
\hline Butte, SD & 27 & 72 & 54.6 & 142.7 & 269.7 \\
\hline Fallon, MT & 29 & 59 & 27.8 & 112.2 & 231.4 \\
\hline Hettinger, ND & 29 & 74 & 8.4 & 76.0 & 270.5 \\
\hline \multicolumn{6}{|c|}{ Missouri Coteau } \\
\hline Kidder, ND & 40 & 93 & 14.6 & 123.8 & 224.0 \\
\hline McPherson, SD & 37 & 105 & 16.2 & 118.2 & 206.9 \\
\hline Sheridan, MT & 29 & 81 & 2.2 & 99.6 & 197.1 \\
\hline \multicolumn{6}{|c|}{ Drift Prairie } \\
\hline Day, SD & 44 & 77 & 9.0 & 64.6 & 134.5 \\
\hline Eddy, ND & 37 & 81 & 4.2 & 74.3 & 200.8 \\
\hline \multicolumn{6}{|c|}{ Black Prairie } \\
\hline Grant, MN & 31 & 57 & 7.1 & 48.3 & 168.6 \\
\hline Total & 303 & 699 & & & \\
\hline
\end{tabular}

by sight and sound. A point count consisted of an observer standing at a fixed location for $5 \mathrm{~min}$ and recording all indicated breeding pairs seen or heard within $100 \mathrm{~m}$. Birds that were flying over were counted only if they were actually using the circular plot, such as for foraging, displaying, etc. Counts began when the observer reached the survey point. Point counts were conducted from dawn to early afternoon under suitable weather conditions (no precipitation or strong winds). Surveys were conducted between 31 May and 2 July 1995. Some point counts encompassed areas outside the CRP field. In most cases, the outside area consisted of substantially similar grassland vegetation (e.g. pasture, other CRP field, hayland). The 14 points containing more than $1 \%$ woody vegetation or more than $20 \%$ cropland were omitted from analysis.

Patch-size determination.-Land use and cover were determined by using a combination of aerial photograph interpretation and ground truthing. Color aerial slides (taken primarily in 1992) were obtained from county offices of the U.S. Department of Agriculture, Agriculture Stabilization and Conservation Service (now Farm Services Agency). For each focal CRP field, a raster object was created from the aerial slide with Map and Image Processing System (MIPS) software (MicroImages, Inc. 1992). Land use and cover within $400 \mathrm{~m}$ of the edge of each focal CRP field were recorded in the field and were manually delineated using MIPS by drawing vectors over scaled rasters. We delineated nine habitat classes: CRP, hayland, grassland, planted cover, cropland, wetland, riparian, woodland, and other (Cowardin et al. 1988, Igl and Johnson 1997). Area estimates of 
habitat types were determined with MIPS to the nearest 0.01 ha. We then calculated the area of contiguous perennial grassland (including the focal CRP field, other CRP fields, hayland, grassland, and planted cover; but excluding fencerows, road and railroad rights-of-way, and field borders) within 400 $m$ of the edge of the focal CRP field.

Analyses for common species.-We related occurrence or density of individual species recorded in circular plots of $100 \mathrm{~m}$ radius in a CRP field to area of contiguous grassland that encompassed (and included) the field. We did a separate analysis for each of up to 15 species in each county; that approach allowed us to account for differences in abundance among counties and to determine if area sensitivity varied from county to county. Analyses were conducted for only those species $\times$ county combinations with more than one occurrence of the species.

We often had multiple circular plots (up to eight) within a CRP field. If plots are more similar within fields than among fields, treating each plot as an independent observation would constitute pseudoreplication (Hurlbert 1984). Accordingly, we developed schemes (described below) to weight observations to account for potential dependence among observations. The net result of the weighting was to reduce effective sample size within a species and county, according to dependence of plots within fields for that species and county. We performed three types of analyses: logistic regression on presence or absence in each plot, linear regression on frequency of occurrence in each field, and linear regression on density in each field.

In the logistic regression on presence or absence, each plot within a field was treated as a (possibly non-independent) sample unit; the response variable was 1 if the species was recorded in the plot and 0 if it was not. We used PROC LOGISTIC in SAS (SAS Institute 1990) and accounted for potential lack of independence among plots within the same field by weighting each observation according to the evident dependence of those plots. Estimates of correlation coefficients $(r)$ of plots within fields were obtained with generalized estimating equations (Liang and Zeger 1986), as implemented in SAS PROC GENMOD (SAS Institute 1996). Values of $r$ were specific to each species and county.

From those $r$ values, we obtained weights $(w)$ to use in logistic regression as

$$
w=1-r(n-1) / n
$$

where $n$ is number of plots within the field. That formulation gives full weight $(w=1)$ to each observation (for a species and county) for which there is no correlation among plots $(r=0)$. For perfectly correlated plots $(r=1)$, each observation would be weighted by $1 / n$, equivalent to having only one, instead of $n$, observations for that field. Weights decline linearly from 1 to $1 / n$ as $r$ increases from 0 to 1 . (For the few species-county combinations for which $r$ was negative, weights of 1 were assigned.)

Our second approach employed linear regression on frequency of occurrence. The response variable in that case was proportion of plots within a field on which a species was detected. Those observations were independent, but varied in precision because of the unequal number of plots on which frequency of occurrence was based. Each observation (field) was weighted by $v$. The $v$ values were selected to give greater weight, but not proportional weight, to fields with more plots censused, and to incorporate also the correlation among plots within a field. It used the same $r$ values determined above, and gave weights

$$
v=V_{n}-r\left(V_{n}-1\right)
$$

That equation gave weights ranging from $v=V_{n}$ when $r=0$ to $v=1$ when $r=1$.

Our third analytic approach involved linear regression on the density in a field. For this, we summed numbers of indicated pairs recorded in all plots in a field, and divided the result by total area of those plots. Analyses used the same weighting scheme described above for linear regression on frequency of occurrence.

We used Akaike's Information Criterion (AIC; Burnham and Anderson 1998) to determine if patch size should be included in each model. Maximum AIC values are attained for models that fit the data well with the fewest parameters. We present results primarily from the logistic regression on presence or absence, because it is the most natural technique for use with binary data, and secondarily from the linear regression on frequency of occurrence or density.

Although $P$ values resulting from statistical tests can be misleading (Johnson 1999), we do present some of them. Because our samples were not excessively large, $P$ values are unlikely to mislead us into declaring that a small effect is significant, and we do not use $P$ values to accept the null hypothesis. Models were selected on the basis of their AIC values; the presented $P$ values associated with model selection reflect the increase in log likelihood associated with inclusion of patch size in the model.

We conducted further analyses on results of the logistic regression on presence or absence. We examined individual patch-size regression coefficients, and any relation they have with abundance of the species or with latitude or longitude of the county. Abundance was estimated from our general transect surveys of CRP fields (Johnson and Schwartz 1993a) in that county in 1995, not from the point counts themselves. Latitude and longitude measurements were of the midpoint of each county.

Logistic regression coefficients also were used in a meta-analysis. Significance of patch size in each logistic regression was measured by a $Z$ statistic, calculated as the estimated patch-size regression coefficient divided by its estimated standard error. That 
TABLE 2. Effects of patch size on grassland birds in CRP fields in nine counties in the northern Great Plains.

\begin{tabular}{|c|c|c|c|c|c|c|c|c|c|}
\hline Species & Butte & Day & Eddy & Fallon & Grant & $\begin{array}{c}\text { Hettin- } \\
\text { ger }\end{array}$ & Kidder & $\begin{array}{l}\text { McPher- } \\
\text { son }\end{array}$ & $\begin{array}{c}\text { Sheri } \\
\text { dan }\end{array}$ \\
\hline Northern Harrier & - & - & - & - & - & & - & $+\mathrm{D}$ & - \\
\hline Mourning Dove & & & & & - & & & -PFD & \\
\hline Eastern Kingbird & + PFD & - & & & - & & & & - \\
\hline Sedge Wren & - & & & - & & - & & $+\mathrm{PD}$ & - \\
\hline Common Yellowthroat & - & & & - & $+\mathrm{D}$ & $-\mathrm{P}$ & & & - \\
\hline Clay-colored Sparrow & - & & & 一 & $+\mathrm{PFD}$ & & $+\mathrm{D}$ & & $+\mathrm{D}$ \\
\hline Grasshopper Sparrow & & & & +PFD & & $+\mathrm{PD}$ & & -PFD & \\
\hline Baird's Sparrow & + PFD & & - & $+\mathrm{D}$ & & & & & \\
\hline Le Conte's Sparrow & - & & & - & $+\mathrm{F}$ & - & & & \\
\hline Lark Bunting & & - & - & & - & & - & - & - \\
\hline Savannah Sparrow & $-\mathrm{P}$ & & & - & & & & & $+\mathrm{D}$ \\
\hline Bobolink & - & & $+\mathrm{PF}$ & - & $+\mathrm{P}$ & $+\mathrm{PFD}$ & $+\mathrm{D}$ & & - \\
\hline Western Meadowlark & & & & $+\mathrm{D}$ & - & $-\mathrm{P}$ & & & \\
\hline Red-winged Blackbird & $+\mathrm{D}$ & & & $+\mathrm{D}$ & & & $-\mathrm{P}$ & $-\mathrm{PF}$ & \\
\hline Brown-headed Cowbird & - & & $-\mathrm{P}$ & - & & & & & \\
\hline
\end{tabular}

Results are denoted " $\mathrm{P}$ " for logistic regression on presence or absence data, " $\mathrm{F}$ " for linear regression on frequency of occurrence, and " $\mathrm{D}$ " for linear regression on density. Upper-case letters indicate that patch size was included in model selected by Akaike's Information Criterion. Plus sign (+) indicates that patch size had positive effects on response variable; minus sign $(-)$ indicates negative effects. No entry indicates that patch size was not included in the model. A dash (-) indicates that the species was not common enough in that county to analyze.

scaling helps account for variable levels of precision among coefficients. There were up to nine analyses for each species, one for each county in which it was detected. Under the null hypothesis that the incidence of a species was not influenced by size of the grassland patch, $Z$ values should be independently and identically distributed with a mean of 0 and a variance of 1 . Accordingly, mean of $Z$ values from $m$ counties should be distributed approximately as a normal variable with a mean of 0 and variance $1 / \mathrm{m}$. Further, the sum of squared $Z$ values should be distributed as a chi-square variate with $m$ degrees of freedom. We compared observed values of those statistics to distributions expected under the null hypothesis of no patch-size effect to evaluate the general pattern of area sensitivity. A mean $Z$ value significantly different from zero suggests some overall area sensitivity. A significant chi-square value suggests area sensitivity, but not necessarily in the same direction in all counties. That is, in some counties a species might be more common in large patches, whereas in other counties it could be less common in large patches.

Analyses of uncommon species.-The analyses just described are unsuitable for species that occur infrequently. For those less-common species, we simply present size of patch in which the species was recorded, and compare that size to the distribution of patch sizes associated with points for that county. If there is no area sensitivity, we would expect percentiles to have a uniform distribution between 0 and 100. Favoring of large patches would be reflected in percentile values $>50$.

\section{RESUlTS}

We analyzed data for 15 species of grassland birds. One, Lark Bunting (Calamospiza melanocorys), was detected only in the three southwestern counties, where it was very common. Although patch size was not included in optimal models for any county (Table 2), patches typically were large in counties where the species occurred. No general effect was demonstrated $(P=0.41)$, but there was a tendency for more western counties to have larger coefficients of patch size $(r=0.99, P=0.075)$.

Six species showed fairly consistent preference for larger patches. Northern Harriers (Circus cyaneus) were detected more than once in two counties. Logistic regression coefficients of patch size were positive for both counties, which indicates a preference for larger patches, but patch size was not included in the optimal model for either county (Table 2). Linear regression on density, however, selected a model for $\mathrm{McPherson}$ County that included patch size as a positive effect. We also included Northern Harrier in the analysis for uncommon species. Five of six percentile values exceeded 50 , which suggests that Northern Harriers were encountered at points in large patches more often than expected. All occupied patches exceeded 100 ha.

Clay-colored Sparrow analyses yielded five positive and two negative coefficients. Patch 
size was positive and included in the logistic model for Grant County $(P=0.0025)$ and in linear models for density for Grant, Kidder, and Sheridan counties. Logistic regression coefficients tended to vary positively with density $(r$ $=0.53, n=7, P=0.22$ ).

Baird's Sparrows were common enough to analyze in only three counties. They favored large patches in Butte County, according to the models for presence or absence $(P=0.0007)$ and frequency of occurrence, and in Butte and Fallon counties based on the regression on densities (Table 2).

Bobolinks generally favored larger patches ( $P=0.036$ for average $Z$ value and $P=0.018$ for squared $Z$ ). Four of six logistic regression coefficients were positive, and optimal models for Eddy, Grant, and Hettinger counties included patch size $(P$ values $=0.076,0.027$, and 0.0007 , respectively). Linear regression on densities yielded positive effects of patch size in Hettinger and Kidder counties.

Sedge Wrens (Cistothorus platensis) had positive coefficients in all five counties in which they were found. The average $Z$ value was positive but only marginally significantly different from zero $(P=0.15)$. Patch size was included in models for both presence or absence and density for McPherson County (Table 2). Coefficients tended to be more positive in more northern counties $(r=-0.76, n=5, P=0.14)$.

Evidence of area sensitivity was somewhat weak for two species. Le Conte's Sparrows (Ammodramus leconteii) showed no evidence of area dependency overall $(P=0.78)$, with two positive and four negative coefficients. There was some evidence of a tendency toward greater area sensitivity in more eastern counties $(r$ $=0.67, n=6, P=0.15)$. For frequency of occurrence, patch size was included as a positive influence in the optimal model for Grant County (Table 2).

Western Meadowlarks were found in all counties but Grant County, the easternmost county in our study. Patch size was included in the logistic model for presence or absence $(P=$ 0.031) for Hettinger County, where it was negative; that outcome was driven by data from a single field, however. Otherwise, coefficients were not significant overall $(P=0.30)$ and showed no pattern. Linear regression on densities, however, indicated that Western Mead- owlarks were more common in larger patches in Fallon County.

For Eastern Kingbird (Tyrannus tyrannus), two coefficients were positive and four were negative, and there was no general departure from zero $(P=0.94)$. For Butte County, the patch-size coefficient was positive and significant for the logistic $(P=0.0061)$ and both linear regression analyses, but that result was based on only three detections (among 72 plots).

Savannah Sparrows occurred in all counties, although they were observed only once in Fallon County. Patch size was included in the optimal model, as a positive effect, for density only in Sheridan County (Table 2). Patch size had a negative effect on presence or absence in Butte County, where patches tended to be large. No overall effect was noted $(P=0.54)$. There was a tendency for coefficients to be larger in counties with more Savannah Sparrows $(r=$ $0.57, n=8, P=0.14$ ).

Some suggestion of regional variability in area sensitivity was indicated for three species. Common Yellowthroats (Geothlypis trichas) appeared to favor smaller patches in Hettinger County, based on the logistic regression (Table 2). A preference for larger patches was exhibited in Grant County. There was no consistent evidence of patch-size response overall $(P=$ 0.78 ), and three logistic regression coefficients were positive and three were negative. There was a tendency for greater area sensitivity in counties with higher densities; coefficients were correlated positively with density $(r=$ $0.69, n=6, P=0.13$ ) and negatively with longitude $(r=0.88, n=6, P=0.020)$.

Red-winged Blackbirds (Agelaius phoeniceus) occurred in all nine counties. Coefficients ranged widely, with four positive and five negative. For Kidder and McPherson counties, negative patch-size effects were included in optimal models for presence or absence $(P=0.104$, 0.0093 , respectively; Table 2 ). In contrast, for Butte and Fallon counties linear regression models included patch size as a positive effect in the optimal models. The overall test of the mean regression coefficient was nonsignificant $(P=0.35)$.

Grasshopper Sparrows were recorded in all nine counties. There were slightly more negative (5) than positive (4) coefficients, and no overall tendency ( $P=0.77$ for average $Z$-value). The $P$-value of 0.023 for the sum of their 
squares, however, suggested variation in the species' response to patch size. Regression coefficients in optimal models for presence or absence were positive for Fallon $(P=0.040)$ and Hettinger $(P=0.0042)$ counties, but negative for McPherson County $(P=0.024)$. Linear regression on densities yielded similar results, with positive coefficients for Fallon and Hettinger counties, but negative for McPherson County.

Two species expressed a preference for smaller grassland patches. Mourning Doves (Zenaida macroura) favored smaller grassland patches in McPherson County, under the model for presence or absence $(P=0.0022$; Table 2$)$. Six of the eight coefficients were negative, and the overall effect was negative and nearly significant $(P=0.14)$. There was no spatial pattern to the coefficients or any relation to abundance. Linear regression on densities likewise indicated that Mourning Doves were more common in smaller patches in McPherson County.

Brown-headed Cowbirds (Molothrus ater) also showed an overall tendency to favor small patches $(P=0.099)$. Six of the logistic regression coefficients were negative, versus only one positive. The coefficient of patch size was negative in the optimal model for Eddy County $(P$ $=0.13$ ) (Table 2). Coefficients showed no relationship to the density of cowbirds in a county.

Our analysis of uncommon species includes five species, in addition to the Northern Harrier, which was described above. The two records of Sharp-tailed Grouse (Tympanuchus phasianellus) were in patches of above-average size, exceeding $160 \mathrm{ha}$. The single observation of a Willet (Catoptrophorus semipalmatus) was in a 178 ha patch. The other shorebirds-Marbled Godwit (Limosa fedoa), Upland Sandpiper (Bartramia longicauda), and Wilson's Phalarope (Phalaropus tricolor)-displayed no clear selection for larger-than-average grassland patches, but all were found only in patches exceeding 50 ha, so we have no evidence that they would use small patches.

\section{Discussion}

Our results support or expand on those of others who have addressed area sensitivity in grassland birds, with some exceptions. Most of the 15 species that we examined showed indications of being area-sensitive, but the evidence was not consistent among all counties for some species. We were unable to detect any area sensitivity in Lark Buntings, but the species occurred in 1995 only in the western counties, where most patch sizes were large. No other investigators have reported on area sensitivity in Lark Buntings.

Northern Harriers have large territories (Dechant et al. 1999) and have been widely reported to use extensive grasslands (Hamerstrom 1986), so they might be expected to be area-sensitive. In our study, Northern Harriers were shown to favor larger grassland patches. In contrast, Herkert et al. (1999) suggested that harriers may respond more strongly to total amount of grassland within the landscape rather than to sizes of individual grassland tracts.

In our study, Clay-colored Sparrows tended to favor larger grasslands. Johnson and Temple (1986), the only other authors to report on area requirements of that species, reached the opposite conclusion, however, that they were more common in smaller than in larger prairies. Their methods may render the conclusions somewhat suspect (see above). Clay-colored Sparrows often use shrubby vegetation, which may be more likely to have invaded the periphery, than the interior, of native grasslands such as Johnson and Temple (1986) studied. Accordingly, smaller patches would contain a greater proportion of shrubby vegetation, and thereby more suitable habitat for Clay-colored Sparrows. Because our fields had been planted with grasses and legumes relatively recently (Johnson and Schwartz 1993b), invasion of woody vegetation along the periphery was uncommon; Clay-colored Sparrows built their nests mostly in alfalfa and standing residual vegetation in our study fields.

Our finding of area sensitivity for Baird's Sparrow was consistent with that of McMaster and Davis (1998), who recorded higher frequencies of occurrence of the species at sites surrounded by more grassland habitat in Saskatchewan. This grassland-dependent species is fairly intolerant of cultivation (Owens and Myres 1973) and tends to avoid areas that contain extensive woody vegetation (Madden 1996 ) or that occur near roads (Sutter et al. 2000).

Bobolinks were reported to be area-sensitive by Herkert (1994), Vickery et al. (1994), and Bollinger (1995), as well as in our study. Helzer 
(1996) indicated that Bobolinks avoided edges near woody vegetation, although Wiens (1969) did not observe that pattern. In Colorado, Bock et al. (1999) suggested that Bobolinks avoided grasslands near suburban edges.

Our results suggest that the Sedge Wren is area-sensitive. Herkert (1994), in contrast, noted no effect of patch size on Sedge Wren densities in native and tame grasslands in Illinois. Sedge Wrens tend to avoid cropland (Johnson and Igl 1995) and extensive woody vegetation (Sample 1989).

We found some indication of area sensitivity in Le Conte's Sparrows. No other studies have examined area sensitivity in this species. Le Conte's Sparrows tend to avoid areas with extensive woody vegetation (Madden 1996).

Our results for area sensitivity of Western Meadowlarks were inconclusive. McMaster and Davis (1998) and Knick and Rotenberry (1995) found no patch-size effect for that species. Relative to other passerines in grasslands, this species tends to have large territories that are not confined to single fields (e.g. Frawley 1989). Western Meadowlarks tend to avoid areas with extensive woody vegetation (Sample 1989). Herkert (1994) and Vickery et al. (1994), but not Bollinger (1995) or Winter and Faaborg (1999), found its congener, the Eastern Meadowlark (Sturnella magna), to be area-sensitive.

Our evidence for area sensitivity in Savannah Sparrows was weak. Herkert (1994), Vickery et al. (1994), and Bollinger (1995), however, all found that Savannah Sparrows were more common in larger fields. Wiens (1969) noted their aversion to woody edges and cultivated fields, and Bock et al. (1999) found them more abundant on interior plots than on edge plots. Most of those studies were conducted in the more fragmented tallgrass prairies and other grasslands of the East or Midwest, which might account for the difference. For example, Vickery et al. (1994) reported that Savannah Sparrows reached $50 \%$ of their maximum incidence at about 10 ha, which is much smaller than nearly all of our grassland patches.

We detected some regional variability in area sensitivity of Common Yellowthroats. Inconsistent results for that species likewise were reported by other investigators: Vickery et al. (1994) found them more common in smaller patches, but Herkert (1994) indicated no influence of patch size. We suspect that Common
Yellowthroats are selecting habitat features, such as wet areas, patches of dense vegetation, or brushy thickets, rather than keying on size of the grassland.

Our inconsistent results for Red-winged Blackbirds were similar to those of other studies. Herkert (1994) reported that redwings were more common on small prairies, but Bollinger (1995) found no effect of patch size. As with Common Yellowthroat, it is likely that this species responds to proximate habitat features, such as presence of tall, dense herbaceous cover or fencerows for song perches, rather than to the size of a grassland patch itself.

Our results that indicate regional variability in area sensitivity among populations of Grasshopper Sparrows differ from most studies, in which the species has consistently been reported as being area-sensitive (Herkert 1994, Vickery et al. 1994, Bollinger 1995, McMaster and Davis 1998). Grasshopper Sparrows also have been noted to avoid edges (Wiens 1969, Johnson and Temple 1990, Helzer 1996, Bock et al. 1999). In southwestern Missouri, however, Grasshopper Sparrows were not found to be area-sensitive (Winter and Faaborg 1999).

In our study, Mourning Doves were more common in small than in large patches. Mourning Doves generally avoid extensive forests or grasslands and tend to prefer open woodlands and edges between grasslands and forests (Tomlinson et al. 1994). Because small patches may be composed almost entirely of edge habitat, Mourning Doves would occur at higher densities in smaller grassland patches. We are not aware of any other studies that have examined area sensitivity of Mourning Doves in grasslands.

Brown-headed Cowbirds, one of the most common edge species in the northern Great Plains (Igl and Johnson 1997), also favored small grassland patches in our study. Because our CRP fields lacked cattle or other attractions for cowbird foraging, and the uniformity of vegetation within fields did not provide outstanding perch sites except near edges (e.g. fencerows), cowbirds probably made less use of the interiors of larger patches, resulting in lower densities in those patches. Patterns of cowbird brood parasitism in the northern Great Plains generally agree with these results. In Manitoba, Davis and Sealy (2000) found higher frequencies of cowbird brood parasit- 
ism in areas with a higher proportion of edge. In western Minnesota, Johnson and Temple (1990) noted higher rates of cowbird parasitism of grassland bird nests along edges between grassland and woodland than in interior grassland. In southern Saskatchewan, the density of cowbirds was lower in large pastures than in small pastures (S. K. Davis, Saskatchewan Wetland Conservation Corp., Regina, pers. comm.).

Inconsistent findings of area sensitivity among or even within a single study could have arisen from any of several causes. Possibly the species was area-sensitive, but the study did not detect it (a Type II error in the parlance of hypothesis testing). Or the reverse might have occurred, with an effect reported due only to chance (a Type I error), which is usually much less likely than a Type II error. Differences in study designs or analytic methods among studies also can result in inconsistencies in reported results. Species may respond differently in different portions of their breeding range-for example, in the core versus the periphery. Certainly variable responses to patch size are likely in landscapes with different amounts of suitable habitat (Donovan et al. 1997). Further, types of edges that delimit grassland patches vary from one area to another, which can influence area sensitivity. Finally, birds may respond differently to patch sizes depending on abundance of the species in the region. We found evidence of that phenomenon for three species.

The greater apparent area-sensitivity for those species in counties where they were more common defies easy explanation. Area sensitivity reflects a habitat choice, so theories about habitat selection are applicable. For example, under the ideal-free habitat distribution of Fretwell and Lucas (1970), birds would have a greater choice of habitats in areas where the species' density was low, relative to the amount of suitable habitat. The principal assumption of the Fretwell-Lucas model is that suitability of a habitat for a species declines with increasing density of the species. Superficially, at least, one would then expect less area sensitivity where the species was more abundant and birds could not be as discriminating.

Suppose, however, that grassland habitats are not equally suitable among counties. (In our situation with CRP fields, planting mixtures varied regionally [Johnson and Schwartz 1993b], and edaphic conditions, climate, and a range of other influences certainly varied as well.) Conceivably, a county might have higher densities of a species because the habitat for that species was more suitable than in counties with lower densities. Then, even though densities in that county were higher, the birds may not have saturated the suitable habitat as completely as birds in other counties. Therefore, the birds could be more selective; that is, they could exhibit greater area sensitivity.

We lack, unfortunately, detailed knowledge of the exact features that influence habitat suitability, and how suitability might vary regionally or among available habitats. Rather than speculating further, it seems more appropriate to await other studies and determine if they yield similar findings.

Our study illustrates potential shortcomings of individual studies of area requirements, especially those conducted in a single area. For no species did we obtain consistent and conclusive results from all counties. Had we restricted ourselves to Fallon County, for example, we would have inferred that Red-winged Blackbirds favored larger grassland patches. Conversely, we would have declared that same species to favor smaller grasslands if we had only results from McPherson County. True replication is essential, especially in space (Shaver 1993, Johnson 1999).

Findings from our study are valuable both for designing reserves for grassland birds (e.g. Johnson and Winter 1999) and for design and implementation of current and future federal cropland retirement programs (Joyce et al. 1991). Our results indicate that locating a CRP field near existing grassland, or establishing one large CRP field rather than several small ones, would benefit more grassland bird species than would creating small, isolated CRP fields. This conclusion holds especially for true grassland birds-such as Baird's Sparrow, Grasshopper Sparrow, and Bobolink-as opposed to edge-favoring or generalist species such as Mourning Dove, Eastern Kingbird, and Red-winged Blackbird.

\section{ACKNOWLEDGMENTS}

We are grateful to Michael C. Marlow and Lisa A Murphy for field assistance; to Betty R. Euliss, Christopher J. Johnson, H. Thomas Sklebar, and Kathleen A. Ward for geographical information systems work, 
to Agriculture Stabilization and Conservation Service staff for assistance in locating fields; and to numerous landowners who let us survey birds on their CRP fields. Robert R. Cox, Jr, and Julie L. Yee offered valuable statistical counsel. The manuscript benefitted from reviews by Jane E. Austin, Diane A. Granfors, Glen A. Sargeant, and Marsha A. Sovada, as well as by Peter B. Vickery, Jeffrey D. Brawn, and an anonymous referee.

\section{Literature Cited}

Bock, C. E., J. H. Bock, AND B. C. BennetT. 1999. Songbird abundance in grasslands at a suburban interface on the Colorado High Plains. Studies in Avian Biology 19:131-136.

Bollinger, E. K. 1995. Successional changes and habitat selection in hayfield bird communities. Auk 112:720-730.

BOND, R. R. 1957. Ecological distribution of breeding birds in the upland forests of southern Wisconsin. Ecological Monographs 27:351-384.

BurnhaM, K. P., AND D. R. ANDERSON. 1998. Model Selection and Inference: A Practical Information-Theoretic Approach. Springer-Verlag, New York.

CONNOR, E. F., AND E. D. MCCOY. 1979. The statistics and biology of the species-area relationship. American Naturalist 113:791-832.

CoWARdin, L. M., D. H. Johnson, T. L. ShafFER, AND D. W. SPARLING. 1988. Application of a simulation model to decisions in Mallard management. U.S. Fish and Wildlife Service, Technical Report 17.

Davis, S. K., AND S. G. SEAly. 2000. Cowbird parasitism and nest predation in fragmented grasslands of southwestern Manitoba. Pages 220-228 in The Ecology and Management of Cowbirds and their Hosts (J. N. M. Smith, T. Cook, S. I. Rothstein, S. K. Robinson, and S. G. Sealy, Eds.). University of Texas Press, Austin.

Dechant, J. A., M. L. Sondreal, D. H. Johnson, L. D. IGL, C. M. Goldade, M. P. Nenneman, AND B. R. EuLISS. 1999. Effects of management practices on grassland birds: Northern Harrier. Unpublished report. U.S. Geological Survey, Northern Prairie Wildlife Research Center, Jamestown, North Dakota.

Delisle, J. M., AND J. A. SAvidGE. 1996. Reproductive success of Grasshopper Sparrows in relation to edge. Prairie Naturalist 28:107-113.

Dinsmore, J. J. 1994. A Country So Full of Game: The Status of Wildlife in Iowa. University of Iowa Press, Iowa City.

Donovan, T. M., P. W. Jones, E. M. ANNAND, AND F. R. THOMPSON III. 1997. Variation in local-scale edge effects: Mechanisms and landscape context. Ecology 78:2064-2075.
FRAWLEY, B. J. 1989. The dynamics of nongame bird breeding ecology in Iowa alfalfa fields. M.S. thesis, Iowa State University, Ames.

FRETWELL, S. D., AND H. L. LuCAS, JR. 1970. On territorial behavior and other factors influencing habitat distribution in birds. I. Theoretical development. Acta Biotheoretica 19:16-36.

GATES, J. E., AND L. W. GySEL. 1978. Avian nest dispersion and fledging success in field-forest ecotones. Ecology 59:871-883.

HAILA, Y., AND O. JÄRVINEN. 1981. The underexploited potential of bird censuses in insular ecology. Studies in Avian Biology 6:559-565.

HAMERSTROM, F. 1986. Harrier: Hawk of the Marshes. Smithsonian Institution Press, Washington, D.C.

HedGes, L. V., AND I. OLKIN. 1985. Statistical Methods for Meta-analysis. Academic Press, New York.

Helzer, C. J. 1996. The effects of wet meadow fragmentation on grassland birds. M.S. thesis, University of Nebraska, Lincoln.

Herkert, J. R. 1994. The effects of habitat fragmentation on midwestern grassland bird communities. Ecological Applications 4:461-471.

Herkert, J. R., S. A. Simpson, R. L. Westmeier, T. L. ESKER, AND J. W. WALK. 1999. Response of Northern Harriers and Short-eared Owls to grassland management in Illinois. Journal of Wildlife Management 63:517-523.

Hurlbert, S. H. 1984. Pseudoreplication and the design of ecological field experiments. Ecological Monographs 54:187-211.

IGL, L. D., AND D. H. Johnson. 1997. Changes in breeding bird populations in North Dakota: 1967 to 1992-93. Auk 114:74-92.

JoHNSON, D. H. 1996. Terrestrial bird communities on the Woodworth Study Area. Proceedings of the North Dakota Academy of Science 50:127131.

JOHNSON, D. H. 1999. The insignificance of statistical significance testing. Journal of Wildlife Management 63:763-772.

Johnson, D. H., S. D. HAseltine, AND L. M. CowaRDIN. 1994. Wildlife habitat management on the northern prairie landscape. Landscape and Urban Planning 28:5-21.

Johnson, D. H., AND L. D. IGL. 1995. Contributions of the Conservation Reserve Program to populations of breeding birds in North Dakota. Wilson Bulletin 107:709-718.

Johnson, D. H., AND M. D. SchWARtz. 1993a. The Conservation Reserve Program and grassland birds. Conservation Biology 7:934-937.

Johnson, D. H., AND M. D. Schwartz. 1993b. The Conservation Reserve Program: Habitat for grassland birds. Great Plains Research 3:273295.

JOHNSON, D. H., AND M. WINTER. 1999. Reserve design for grasslands: Considerations for bird pop- 
ulations. Proceedings of the Tenth George Wright Society Biennial Conference:391-396.

Johnson, R. G., AND S. A. Temple. 1986. Assessing habitat quality for birds nesting in fragmented tallgrass prairies. Page 245-249 in Wildlife 2000: Modeling Habitat Relationships of Terrestrial Vertebrates (J. Verner, M. L. Morrison, and C. J. Ralph, Eds.). University of Wisconsin Press, Madison.

JoHnson, R. G., AND S. A. Temple. 1990. Nest predation and brood parasitism of tallgrass prairie birds. Journal of Wildlife Management 54:106111.

Joyce, L. A., J. E. Mitchell, AND M. D. SKold, Eds. 1991. The conservation reserve-Yesterday, today and tomorrow. U.S. Forest Service General Technical Report RM-203. Washington, D.C.

KNICK, S. T., AND J. T. ROTENBERRY. 1995. Landscape characteristics of fragmented shrubsteppe habitats and breeding passerine birds. Conservation Biology 9:1059-1071.

LIANG, R. I., AND S. L. ZEGER. 1986. Longitudinal data analysis using generalized linear models. Biometrika 73:13-22.

MAdDen, E. M. 1996. Passerine communities and bird-habitat relationships on prescribe-burned, mixed-grass prairie in North Dakota. M.S. thesis, Montana State University, Bozeman.

MCMAster, D. G., AND S. K. DAVIS. 1998. Non-game evaluation of the Permanent Cover Program. Unpublished report, Saskatchewan Wetland Conservation Corporation, Regina.

MicroImAges, INC. 1992. A Guide to Map and Image Processing. MicroImages Press, Lincoln, Nebraska.

Owens, R. A., AND M. T. Myres. 1973. Effects of agriculture upon populations of native passerine birds of an Alberta fescue grassland. Canadian Journal of Zoology 51:697-713.

Peden, D. G., G. M. Van Dyne, R. W. Rice, and R. M. HANSON. 1974. The trophic ecology of Bison bison L. on shortgrass plains. Journal of Applied Ecology 11:489-497.

Peterjohn, B. G., And J. R. SAuer. 1999. Population status of North American species of grassland birds from the North American Breeding Bird Survey, 1966-1996. Studies in Avian Biology 19: $27-44$.

RobBins, C. S., D. BYSTRAK, AND P. H. GEISSLER. 1986. The breeding bird survey: Its first fifteen years, 1965-1979. U.S. Fish and Wildlife Service Resource Publication No. 157.

Robbins, C. S., D. K. Dawson, And B. A. Dowell. 1989. Habitat area requirements of breeding forest birds of the middle Atlantic states. Wildlife Monographs No. 103.

SAMPLE, D. W. 1989. Grassland birds in southern Wisconsin: Habitat preference, population trends, and response to land use changes. M.S. thesis, University of Wisconsin, Madison.

SAMSON, F. B. 1980. Island biogeography and the conservation of prairie birds. Proceedings of the North American Prairie Conference 7:293-305.

SAMSON, F., AND F. KNOPF. 1994. Prairie conservation in North America. BioScience 44:418-421.

SAS INSTITUTE, INC. 1990. SAS/STAT User's Guide, version 6,4 th ed., vol. 2. SAS Institute, Inc., Cary, North Carolina.

SAS InSTITUTE, INC. 1996. SAS/STAT Software: Changes and Enhancements for Release 6.12. SAS Institute, Inc., Cary, North Carolina.

SCHWARTZ, C. C., AND J. E. Ellis. 1981. Feeding ecology and niche separation in some native and domestic ungulates on the shortgrass prairie. Journal of Applied Ecology 18:343-353.

SHAVER, J. P. 1993. What statistical significance testing is, and what it is not. Journal of Experimental Education 61:293-316.

Sutter, G. C., S. K. Davis, AND D. C. Duncan. 2000. Grassland songbird abundance along roads and trails in southern Saskatchewan. Journal of Field Ornithology 71:110-116.

Tewksbury, J. J., S. J. Heil, And T. E. Martin. 1998. Breeding productivity does not decline with increasing fragmentation in a western landscape. Ecology 79:2890-2903.

TOMlinson, R. E., D. D. Dolton, R. R. GeORGe, AND R. E. Mirarchi. 1994. Mourning Dove. Pages 5 26 in Migratory Shore and Upland Game Bird Management in North America (T. C. Tacha and C. E. Braun, Eds.). International Association of Fish and Wildlife Agencies, Washington, D.C.

Vickery, P. D., M. L. HunTer, JR., AND S. M. MELVIN. 1994. Effects of habitat area on the distribution of grassland birds in Maine. Conservation Biology 8:1087-1097.

WiENS, J. A. 1969. An approach to the study of ecological relationships among grassland birds. Ornithological Monographs No. 8.

WIENS, J. A. 1995. Habitat fragmentation: Island $v$ landscape perspectives on bird conservation. Ibis 137(Supplement):97-104.

WINTER, M. 1998. Effect of habitat fragmentation on grassland-nesting birds in southwestern Missouri. Ph.D. dissertation, University of Missouri, Columbia.

WinTER, M., AND J. FAABORG. 1999. Patterns of area sensitivity in grassland-nesting birds. Conservation Biology 13:1424-1436.

Winter, M., D. H. Johnson, J. A. Dechant, T. M. DONOVAN, AND W. D. SvEDARSKY. 1999. Evaluation of the Bird Conservation Area concept in the northern tallgrass prairie, annual report: 1999. Unpublished report. U.S. Geological Survey, Northern Prairie Wildlife Research Center, Jamestown, North Dakota.

Associate Editor: J. Brawn 